\title{
Papers
}

\section{Detection of herpesvirus DNA by the polymerase chain reaction (PCR) in vitreous samples from patients with necrotising retinitis} M L Nogueira, R C Siqueira, N Freitas, J B Amorim, C A Bonjardim, P C P Ferreira,
F Oréfice, E G Kroon
Laboratório de Vírus, Departamento de Microbiologia, Instituto de Ciências Biológicas,

Universidade Federal de Minas Gerais, Av. Antônio Carlos, 6627, 31270-901, Belo Horizonte, MG, Brazil M L Nogueira

J B Amorim

C A Bonjardim

P C P Ferreira

E G Kroon

Serviço de Uveítes, Hospital São Geraldo, Faculdade de

Medicina,

Universidade Federal de Minas Gerais

R C Siqueira

N Freitas

F Oréfice

Correspondence to:

Professor Kroon, Av. Antônio

Carlos, 6627, Pampulha,

Belo Horizonte-MG, Brazil

31270-901

kroone@mono.icb.ufmg.br

Accepted for publication 13 June 2000

\begin{abstract}
Aims-Viral uveitis and retinitis, usually caused by herpesviruses, are common in immunosuppressed patients. The diagnosis of viral anterior uveitis and retinitis is usually clinical. The polymerase chain reaction (PCR) has been used for the diagnosis of some viral infections, especially those caused by herpesviruses. This paper reports the use of PCR in the diagnosis of viral retinitis in vitreous samples from Brazilian patients.

Methods-PCR was used for the diagnosis of necrotising retinitis in vitreous samples from patients from the Hospital São Geraldo, Universidade Federal de Minas Gerais, Brazil. The vitreous samples were collected by paracentesis and stored until analysis. Samples were analysed by PCR using specific primers designed to amplify herpes simplex virus 1 (HSV-1), varicella zoster virus (VZV), or human cytomegalovirus (HCMV). In a case of anterior uveitis, PCR was performed with a sample from the anterior chamber.

Results-Herpesvirus DNA was amplified in 11 of 17 samples. HCVM DNA was detected in nine samples but DNA from HSV-1 and VZV were detected only once each.

Conclusion-These results strongly suggest that PCR could be used for a rapid complementary diagnosis of viral uveitis and retinitis. A prospective study to evaluate the PCR results, clinical evolution, and treatment is imperative to corroborate the real value of PCR in diagnosis and how it could help the clinicians' approach. (f Clin Pathol 2001;54:103-106)
\end{abstract}

Keywords: polymerase chain reaction; uveitis; retinitis

Viral uveitis and retinitis are common clinical findings in immunosuppressed patients. They are usually caused by herpesviruses, especially human cytomegalovirus (HCMV), herpes simplex virus (HSV), and varicella zoster virus (VZV). VZV is the most common agent of acute retinal necrosis (ARN) syndrome and progressive outer retinal necrosis (PORN). PORN is the second most common cause of blindness in patients with AIDS. The ARN syndrome affects both immunosuppressed and non-immunosuppressed patients, and is related to VZV, HSV-1, and, in rare cases, HCMV infection. ${ }^{1-6}$

The diagnosis of viral retinitis is usually based on clinical findings. In HCMV induced retinitis, PORN and ARN show classic clinical features that are sometimes sufficient for the clinical diagnosis. However, in immunosuppressed patients, these clinical features might be atypical and laboratory analysis must be used for the diagnosis and the planning of treatment. $^{245}$

The polymerase chain reaction (PCR) has been used for the diagnosis of some viral infections, especially those caused by herpesviruses. $^{7-12}$

The use of PCR for the diagnosis of viral uveitis and retinitis is described in the literature. Published data suggest that PCR can be used as a reliable complimentary procedure for diagnosis. Verbraak et al showed that PCR could be used to analyse the vitreous humour of patients with necrotising retinitis. ${ }^{13}$ They studied patients with both AIDS and retinitis and detected viral DNA in 11 of 28 patients analysed. Danise et al detected PCR products in 11 of 15 cases studied by using primers for HCMV, VZV, HSV, and toxoplasma. ${ }^{9}$ Abe et al compared the use of PCR and local antibody production for the diagnosis of ARN and HCMV retinitis and concluded that PCR was more specific and sensitive for the detection of the aetiological agents of these diseases. ${ }^{14}$ These data confirm that PCR could be used as a complementary procedure for the diagnosis of viral retinitis.

Here, we report the use of PCR for the diagnosis of necrotising retinitis in a Brazilian hospital. We identified herpesvirus DNA in 11 of the 17 patients studied. One of these patients had a case of anterior uveitis and PCR was used to amplify HSV-1 DNA in the aqueous humour.

\section{Material and methods}

CLINICAL SAMPLES

The 17 samples (16 vitreous humour and one aqueous humour) were from patients of the 
Table 1 Patients' data and viral DNA amplified by the polymerase chain reaction

\begin{tabular}{lll}
\hline Patient & Clinical diagnosis & Viral DNA \\
\hline 1 & ARN, HIV- & HCMV \\
2 & ARN, HIV- & Negative \\
3 & ARN, HIV- & Negative \\
4 & "Viral retinitis", HIV- & Negative \\
5 & "Viral retinitis", HIV- & HCMV \\
6 & Anterior uveitis, HIV- & HSV-1 \\
7 & "Viral retinitis", HIV-, lupus & Negative \\
8 & "Viral retinitis", HIV-, diabetis & Negative \\
9 & "Viral retinitis", HIV-, leukemia & HCMV \\
10 & HCMV retinitis, AIDS & HCMV \\
11 & HCMV retinitis, AIDS & HCMV \\
12 & HCMV retinitis, AIDS & HCMV \\
13 & HCMV retinitis, AIDS & HCMV \\
14 & "Viral retinitis", AIDS & Negative \\
15 & PORN, HIV not done & VZV \\
16 & "Viral retinitis", HIV not done & HCMV \\
17 & "Viral retinitis", HIV not done & HCMV \\
\hline
\end{tabular}

$\mathrm{ARN}$, acute retinal necrosis syndrome; HCMV, human cytomegalovirus; HIV, human immunodeficiency virus; HSV-1, human herpesvirus type 1; PORN, progressive outer retinal necrosis; VZV, varicella zoster virus.

Serviço de Uveítes, Hospital São Geraldo, Brazil. The patients were selected from untreated patients with a clinical diagnosis of retinitis. The group contained five patients with AIDS, three with diverse systemic diseases (lupus, diabetes, and leukaemia), and nine patients who were HIV negative or not tested for HIV infection. Sixteen of these patients had a clinical diagnosis of "viral retinitis" (ARN, PORN, HCMV retinitis, or atypical findings) and one had a diagnosis of anterior uveitis. The same physician $(\mathrm{NF})$, using a standard criterion, ${ }^{134}$ made all the clinical diagnoses. When clinical findings were not conclusive, the patients are assigned as "viral retinitis". Table 1 summarises the patients' clinical data.

The samples were collected by paracentesis, after oral consent, using a 30 gauge, 0.5 inch needle attached to a tuberculin syringe. ${ }^{15}$ For the patient with anterior uveitis, the procedure was similar except that paracentesis was carried out in the anterior chamber. Approximately $100 \mu \mathrm{l}$ of vitreous or aqueous humour (in the patient with anterior uveitis) was collected from each patient and stored at $-20^{\circ} \mathrm{C}$ until used for PCR. These samples were collected for other laboratory analyses and were retrieved from the archive for this study.

VIRUSES

The AD169 strain of HMCV was used as the positive HCMV control (a kind gift from Dr LTM Figueiredo, Faculdade de Medicina de Ribeirão Preto, USP) and the clinical isolates of HSV-1 (EK) and VZV (HC05) described by Nogueira and colleagues ${ }^{12}$ were also used as positive controls.
SAMPLE PREPARATION

A $5 \mu$ aliquot of each sample was denatured with $250 \mathrm{U} / \mathrm{ml}$ of proteinase $\mathrm{K}$ in PCR buffer in a final volume of $50 \mu \mathrm{l}$ by incubating at $56^{\circ} \mathrm{C}$ overnight and then at $99^{\circ} \mathrm{C}$ for 10 minutes. The 1/10 dilution obtained was used in the assay to prevent the action of PCR inhibitors, as described by Wiedbrauck and colleagues ${ }^{16}$ and Nogueira et al. ${ }^{12}$ The samples were stored at $-20^{\circ} \mathrm{C}$ until used in the PCR assay.

\section{PCR ASSAY}

Three sets of primers were used for the PCR assays (table 2). The primers for HSV-1 and VZV were based on the thymidine kinase gene of each virus (GenBank accession numbers V00470 and X04370, respectively) and amplified $1130 \mathrm{bp}$ and $1024 \mathrm{bp}$ PCR products, respectively. The PCR was carried out using the same conditions described by Nogueira et $a l .{ }^{12}$ The HCMV PCR was performed using primers that amplified a $170 \mathrm{bp}$ fragment from the DNA polymerase gene of the HCMV AD169 strain (GenBank accession number $\mathrm{X} 17403)$. The amplification mixture contained $10 \mathrm{pM}$ of each primer, $0.1 \mathrm{mM}$ of each dNTP (Pharmacia, Uppsaala, Sweden), 0.1 U Taq polymerase (Promega, Madison, Wisconsin, USA), Taq buffer, appropriate $\mathrm{MgCl}_{2}$ concentration, $1 \mu$ template, and distilled water to a final volume of $20 \mu \mathrm{l}$. PCR was carried out in a Gene Amp 2400 thermal cycler (Perkin-Elmer, Norwalk, Connecticut, USA).

The amplified PCR products were run on a $1 \%$ agarose gel (for VZV and HSV) or a $2 \%$ agarose gel (HCMV), stained with ethidium bromide, and visualised under a UV light transilluminator.

The PCR was performed with strict adherence to the universal quality control guidelines. We used water without the addition of template as a negative control for sample preparation and PCR procedures. We carried out the sample preparation, reaction mix preparation, amplification, and electrophoresis in separate rooms. Each reaction was performed at least twice and was considered positive only when the fragment of the expected size was amplified at least twice in independent reactions.

\section{Results}

Table 1 summarises the results of PCR amplification from the clinical samples. Figure 1 is a representative gel of four samples analysed by PCR using HCMV specific primers. All samples were positive in this test.

Table 2 Primers and polymerase chain reaction (PCR) conditions

\begin{tabular}{|c|c|c|c|c|c|}
\hline Primers & Sequences & Genes & $\begin{array}{l}\text { Size of anplified } \\
\text { DNA }\end{array}$ & $\begin{array}{l}\mathrm{MgCl}_{2} \\
\text { concentration }\end{array}$ & PCR conditions \\
\hline HSV-1TK & $\begin{array}{l}\text { TkR'-5'tcagttagcctcccccatc } \\
\text { TkF'-5'atggcttcgtacccctgcc }\end{array}$ & Thymidine kinase & $1130 \mathrm{bp}$ & $1 \mathrm{mM}$ & $\begin{array}{l}95^{\circ} \mathrm{C} 1 \mathrm{~min}, 55^{\circ} \mathrm{C} 1 \mathrm{~min}, \\
72^{\circ} \mathrm{C} 1 \mathrm{~min}(35 \text { cycles }) \\
\text { and } 72^{\circ} \mathrm{C} 15 \mathrm{~min}\end{array}$ \\
\hline VZV-TK & $\begin{array}{l}\text { TkR'-5'aggaagtgttgtcctgaacggc } \\
\text { TkF'-5'atgtcaacggataaaaccgatgt }\end{array}$ & Thymidine kinase & $1024 \mathrm{bp}$ & $2 \mathrm{mM}$ & $\begin{array}{l}95^{\circ} \mathrm{C} 1 \mathrm{~min}, 57^{\circ} \mathrm{C} 1 \mathrm{~min}, \\
72^{\circ} \mathrm{C} 1 \mathrm{~min}(35 \text { cycles }), \\
\text { and } 72^{\circ} \mathrm{C} 15 \mathrm{~min}\end{array}$ \\
\hline $\begin{array}{l}\text { HCMV } \\
\text { DNApol }\end{array}$ & $\begin{array}{l}\text { PolF-5'gctatgtttcagatgtcgccgcc } \\
\text { PolR-5'cccacctcgggetc aaacac }\end{array}$ & DNA polymerase & $170 \mathrm{bp}$ & $1.5 \mathrm{mM}$ & $\begin{array}{l}95^{\circ} \mathrm{C} 1 \mathrm{~min}, 62^{\circ} \mathrm{C} 1 \mathrm{~min}, \\
72^{\circ} \mathrm{C} 1 \mathrm{~min}(35 \text { cycles }), \\
\text { and } 72^{\circ} \mathrm{C} 15 \mathrm{~min}\end{array}$ \\
\hline
\end{tabular}

HCMV, human cytomegalovirus; HSV, herpes simplex virus; VZV, varicella zoster virus. 


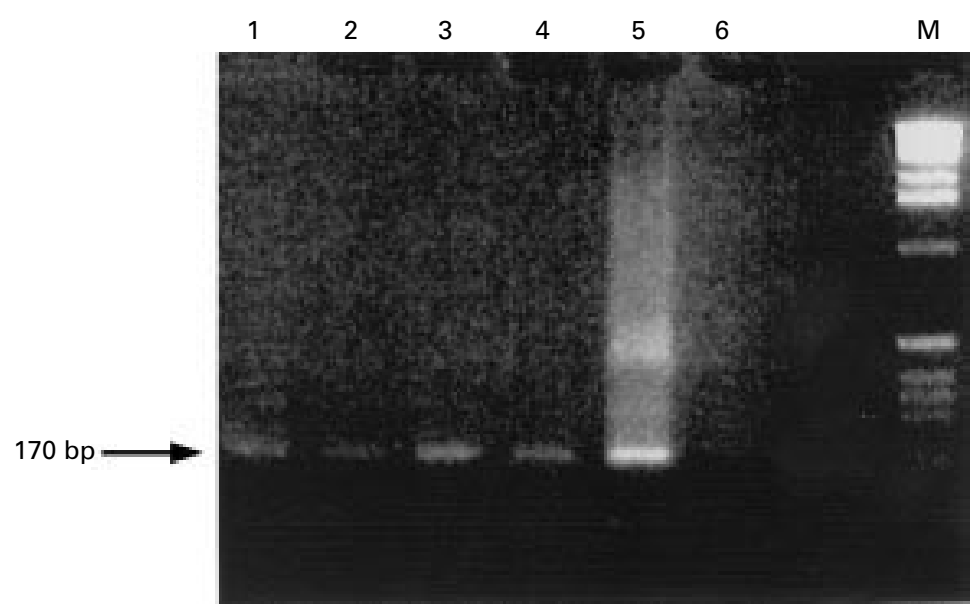

Figure 1 PCR amplification of four samples. The samples were treated with proteinase $K$, amplified by PCR using human cytomegalovirus (CMV) specific primers, electrophoresed in $2 \%$ agarose gel, stained with ethidium bromide, and visualised under UV light (320 nm). Lanes 1-4, positive samples; lane 5, positive control (strain AD169 of human $C M V)$; lane 6 , negative control; and lane $M$, molecular weight marker. The arrow shows a 170 bp fragment.

We studied 17 cases. Four of the five patients with AIDS (patients 10-14) had clinical signs of HCMV retinitis (patients 10-13) and all of these were positive for HCMV by PCR. In the vitreous humour from the patient with AIDS, who had clinical "viral retinitis" (patient 14), no DNA was amplified.

Of 12 patients without AIDS, nine were HIV negative as tested by ELISA (patients 1-9) and in three the test was not performed (patients 15-17).

Three of these 12 patients had a systemic disease (lupus, diabetes, and leukaemia) with a clinical diagnosis of "viral retinitis" (patients 7-9, respectively). Only the patient with leukaemia (patient 9) showed amplification of HCMV and no amplification was seen in the other two cases (patients 7 and 8).

Six patients had no other detected pathological condition apart from the ocular findings (patients 1-6). Three of them had a clinical diagnosis of ARN (patients 1-3) and in only one of these patients was HCMV DNA amplified (patient 1). This is the fifth case in the literature in which HCMV was related to ARN and it will be reported in a separate publication. In one of the two patients with a clinical diagnosis of "viral retinitis" (patients 4 and 5) we amplified HCMV DNA, and we amplified HSV-1 DNA from the aqueous humour of the patient with a clinical diagnosis of anterior uveitis (patient 6).

In three patients (patients 15-17) the HIV status was undetermined; two had a clinical diagnosis of "viral retinitis" and one of PORN. In two of these patients HCMV DNA was amplified (16-17) and in the patient with PORN, VZV DNA was amplified.

\section{Discussion}

PCR has been used for the molecular diagnosis of several infections, especially those related to viral diseases. ${ }^{17}$ In herpesviruses infections, samples derived from many different sites of infection, such as mucocutaneous, nervous, and ocular infections, have been used for diagnosis by PCR..$^{7-12}$
Uveitis and retinitis are common infections in patients with AIDS and $15-40 \%$ of such patients develop HCMV retinitis or other herpesvirus infections in the eyes at some time. $^{5}{ }^{6} 18-20$

We were able to detect herpesvirus DNA in $65 \%$ of the cases analysed, in agreement with the literature. To prevent the action of PCR inhibitors in the samples, we used a 1/10 dilution in PCR buffer and proteinase K digestion, either overnight or for one hour. Some samples that were negative when undiluted became positive only after dilution (ML Nogueira and EG Kroon, unpublished data, 2000). Garweg et $a l,{ }^{8}$ de Boer et $a l,{ }^{15}$ and Danise and colleagues ${ }^{9}$ boiled their samples before PCR, despite the fact that Wiedbrauck and colleagues ${ }^{16}$ described a PCR inhibitor in the vitreous humour that was resistant to boiling for up to 15 minutes.

Amplified HCMV DNA was detected in all of the cases for which HCMV retinitis was suspected by clinical examination. Danise et al also showed amplification of HCMV DNA in samples from all patients with clinically suspected HCMV retinitis. ${ }^{9}$ Garweg and colleagues ${ }^{8}$ demonstrated HCMV DNA amplification in 12 of 14 cases studied, and Verbraak and colleagues $^{13}$ showed HCMV DNA amplification in all 13 cases with a clinical diagnosis of HCMV retinitis.

These data strongly suggest that there is a direct correlation between the clinical diagnosis of HCMV retinitis and the laboratory data, and PCR should be used to diagnose retinitis of unclear aetiology or with atypical manifestations.

We detected herpesviruses other than HCMV in two patients. In each case, VZV DNA or HSV-1 DNA was amplified. Garweg and colleagues ${ }^{8}$ and Verbraak and colleagues ${ }^{13}$ did not detect VZV DNA in 28 cases of necrotising retinitis; however, Danise et al detected VZV DNA in one of two patients with suspected VZV retinitis. ${ }^{9}$ Short et $a l^{21}$ studying a series of 14 cases of PORN, found VZV DNA in 11 cases, but they studied cases of PORN in which VZV was the most common aetiological agent.

Mitchell et al also found that the clinical discrimination between HCMV and VZV associated retinitis was enhanced when PCR were taken into consideration. ${ }^{22}$ These data, and data from others, suggested that a rapid complementary approach using PCR could be valuable in detecting the aetiological agent of necrotising retinitis.

In anterior uveitis, the use of PCR was described by Yamamoto et al $(1996)^{23}$ and by Schacher et al (1998). ${ }^{24}$ Yamamoto et al described PCR in 11 patients with suspected herpesvirus associated uveitis and amplified viral DNA in 10 cases. $^{23}$ These authors concluded that the detection of herpesvirus DNA is useful to support the clinical diagnosis of viral uveitis. However, Schacher et al concluded that neither enzyme linked immunosorbent assay (ELISA) nor PCR were sensitive enough to establish a viral aetiology in several cases of uveitis. ${ }^{24}$ 
Because herpesviruses have different susceptibilities to antivirals, the rapid and precise diagnosis of the correct herpesvirus involved in a specific pathology is very important. Using the incorrect antiviral or, using a lower dose than necessary, are the most important factors in the development of antiviral resistance. ${ }^{25} 26$ In this context, PCR is a rapid and precise methodological tool to determine the aetiological agent involved in the pathogenesis of necrotising retinitis.

We have shown that PCR can be used for the rapid complementary diagnosis of viral uveitis and necrotising retinitis in samples from Belo Horizonte-Brazil. A prospective study to evaluate the PCR results, the clinical evolution, and treatment is imperative to determine the real value of PCR diagnosis and how it could help the clinicians' approach.

We are grateful to JR Santos, AF Carvalho, AS Lopes, IMV Gama, BJ Martins, and MA Souza for technical assistance. We also thank CNPq, FAPEMIG, and CAPES for financial also thank CNPq, FAPEMIG, and CAPES for financial support. MLN, PCPF, EGK, and JBA are recipients of CNPq
fellowships. MLN was a recipient of a FAPEMIG PhD fellowship.

1 Holland GN, Pepose JS, Petit TH, et al. Acquired immunodeficiency syndrome, ocular manifestations. Ophthalmology deficiency syndrom

2 Freeman WR, Lerner CW, Mines JA, et al. A prospective study of the ophthalmologic findings in the acquired immune deficiency syndrome. Am $\mathcal{F}$ Ophthalmol 1984;97: 133-42.

3 Holland GN. The progressive outer retinal necrosis syndrome. Int Ophthalmol 1994;18:163-5.

Holland GN and The Executive Commitee of the American Uveitis Society. Standard diagnostic criteria for the acute retinal necrosis syndrome. Am 7 Ophthalmol 1994;117:663 7.

5 Shuttleworth G, Shimeld C, Easty D. Viral disease of the eye. In: Richman DD, Whitley RJ, Hayden FG, eds. Clinical virology. New York: Churchill Livingstone, 1997:15984 .

6 Griffiths PD, Emery VC. Cytomegalovirus. In: Richman DD, Whitley RJ, Hayden FG, eds. Clinical virology. New York: Churchill Livingstone, 1997:445-70.

7 Nahass GT, Goldstein BA, Zhu WY, et al. Comparison of Tzank smear, viral culture and DNA diagnostic methods in Tzank smear, viral culture and DNA diagnostic methods in detection of herpes simplex

8 Garweg J, Fenner T, Böhnke $M$, et al. An improved technique for the diagnosis of viral retinitis from samples of aqueous humor and vitreous. Graefes Arch Clin Exp Ophthalmol 1993;231:508-13.

9 Danise A, Cinque P, Vergani S, et al. Use of polymerase chain reaction assay of acqueous humor in the differential diagnosis of retinitis in patients infected with human immunodeficiency virus. Clin Infect Dis 1997;24:1100-6.

10 Dennet C, Cleator GM, Klapper PE. HSV-1 and HSV-2 in herpes simplex encephalitis: a study of sixty-four cases in the United Kingdom. F Med Virol 1997;53:1-3.

11 Boivin G, Handfield J, Toma E et al. Evaluation of the AMPLICOR cytomegalovirus test with specimens from human immunodeficiency virus-infected subjects. f $C$ in Microbiol 1998;36:2509-13.

12 Nogueira ML, Carvalho AF, Barbosa EF, et al. Diagnosis of mucocutaneous herpetic infections by PCR without DNA extraction. Mem Inst Oswaldo Cruz 1998;93:213-14.

13 Verbraak FD, Galema M, Van den Horn GH, et al. Serological and polymerase chain reaction-based analysis of aqueous humour samples in patients with AIDS and necrotizing retinitis. AIDS 1996;10:1091-9.

14 Abe T, Tsuchida K, Tamai M. A comparative study of the polymerase chain reaction and local antibody production in acute retinal necrosis syndrome and cytomegalovirus retinitis. Graeffes Arch Clin Exp Ophthalmol 1996;234:41924.

15 de Boer JH, Verhagen C, Bruinenberg M, et al. Serologic and polymerase chain reaction analysis of intraocular fluids in the diagnosis of infectious uveitis. Am 7 Ophthalmol 1996;121:650-8.

16 Wiedbrauk DL, Werner JC, Drevon AM. Inhibition of PCR by aqueous and vitrous fluids. F Clin Microbiol 1995;33: 2643-6.

17 Clewley JP, ed. The polymerase chain reaction for human viral diagnosis. Boca Ratton: CRC Press, 1995.

18 Pepose JS, Holland GN, Nestor MS, et al. Acquired immune deficiency syndrome: pathogenic mechanisms of ocular disease. Ophthalmology 1985;92:474-84.

19 Brown HH, Glasgow BJ, Holland GN, et al. Cytomegalovirus infection of the conjunctiva in AIDS. Am f Ophthalmol 1988;106:102-4.

20 Muccioli C, Belfort Junior R, Lottenberg C, et al. Achados oftalmológicos em AIDS: avaliação de 445 casos atendidos em um ano. Rev Assoc Med Bras 1994;40:155-8.

21 Short GA, Margolis TP, Kupperman BD, et al. Polymerase chain reaction-based assay for diagnosing varicella-zoster virus retinitis in patient with acquired immunodeficiency syndrome. Am f Ophthalmol 1997;123:157-64.

22 Mitchell SM, Fox JD, Tedder RS, et al. Vitreous fluid sampling and viral genome detection for the diagnosis of viral retinitis in patients with AIDS. $\mathcal{F}$ Med Virol 1994;43:33640

23 Yamamoto S, Pavan-Langston D, Kinoshita S, et al. Detection of herpesvirus DNA in uveitis using polymerase chain reaction. Br f Ophthalmol 1996;80:465-8.

24 Schacher S, Garweg JG, Russ C, et al. Diagnosis of herpetic uveitis and keratouveitis. Klin Monatsbl Augenheilkd 1998; 212:359-62.

25 O'Brien JJ, Campoli-Richards DM. Acyclovir: an update review of its antiviral activity, pharmokinetic properties and therapeutic efficacy. Drugs 1989;37:233-309.

26 Field HJ, Goldthorpe SE. The pathogenicity of drugesistant variants of herpes simplex virus. Res Virol 1992;143:120-4. 